\title{
Alternative Online Learning Using Social Media as a Panacea
}

\author{
https://doi.org/10.3991/ijet.v16i07.21209 \\ Luhung Achmad Perguna $\left({ }^{凶}\right)$ \\ Universitas Negeri Malang, Malang, Indonesia \\ luhung.fis@um.ac.id \\ Netty Apriyanti \\ Universiti of Malaya, Kualalumpur, Malaysia \\ Dedeh Kurniasih \\ Universitas Muhammadiyah Pontianak, Pontianak, Indonesia
}

\begin{abstract}
Due to the pandemic crisis, online learning and teaching have become a new normal activity. This study explores a popular and flexible learning media for students in areas with low internet penetration. This paper presents alternative learning using social media and the difference between before and during the crisis. This article has found a change in social media usage as a communication and socialization medium to a learning medium. The three learning methods of social media usage are as follows: question and answer; questioning, and collecting assignments. Social media was chosen because of its popularity and flexibility for both lecturers and students. The aspects of accessibility (cost and connectivity) are a challenge in the development of online learning. Social media is proven to be effective and efficient in conveying messages and to achieve learning objectives.
\end{abstract}

Keywords - Social Media, Online Learning, Accessibility, Crisis, Difference

\section{Background}

The Covid-19 shakes the world. The World Health Organization (WHO) claimed it as a pandemic. This pandemic clearly affecting all aspects of human life including the global economy [1], [2]. Many countries have fallen into recession. This tragedy not only shook the economic sector but also the education sector. At least 46 countries in five continents have announced school closure and 26 of these countries have shuts schools nationwide [3]. The same path is conducted in Indonesia. This pandemic outbreak has forced education institutions such as schools and colleges to shut down due to fears of the massive spread of this epidemic if face-to-face activities continued being enforced [4]. The usual face-to-face teaching and learning activities are halted for an 
unknown period of time. The Indonesian government has limited community mobilization and continues to intensify its agendas of Working from Home (WFH) and Studying from Home (SFH) [5].

In response to $\mathrm{SFH}$, education institutions are optimizing the use of information and communication technology (ICT) in the form of e-learning with a variety of implementations, models, and applications. Studies on the effectiveness, accessibility, affordability, and flexibility of ICT usage in learning have been widely considered from schools to universities [6]-[9]. Many benefits of implementing ICT with e-learning are explored in normal situations [10]-[12].

The application of ICT in online learning is very dependable on hardware and software support. Hardware is gadgets such as smartphones, tablets, computers, and laptops that can be used to access information in real-time and in any place. Meanwhile, the software is a virtual service that can be used by students, such as Google classroom, Google meeting, Zoom, Edmodo, Schoology, and others [13]-[15]. This includes web 2.0-based social media usage services such as Facebook, Instagram, YouTube, WhatsApp, and many others [16]-[18]. This support will not succeed without being followed by Internet capabilities and infrastructure. In general, the highest internet penetration is still contributed by the Java region with $56.6 \%$ of the total population in Indonesia, with Papua in the last position at $3 \%$. The Kalimantan region which is predicted to be the new capital has a contribution of $6.3 \%$.

With many advantages and benefits, ICT (e-learning as its derivative) is considered capable of answering problems due to crisis. For education institutions that have adequate provisions and tools, they can adapt quickly. This also includes students who live in urban areas; accessibility factors, affordability, and flexibility are an easy matter. Meanwhile, education institutions with limited provisions or have hardly used ICT will have difficulty performing its application [19].

The application of e-learning still faces many obstacles such as technology infrastructure support; teacher, and student competence; resistance to change; technology satisfaction, and instructors' motivation [20], [21]. Many higher education institutions have yet to succeed due to bad strategies, high technology costs, resistance to change, competition, and poor course delivery [22], [23]. This problem may differ in areas where internet penetration is still low, such as Pontianak city. However, the experience generated by e-learning in education goes way beyond entertainment [24]. For this reason, more and more higher education is using e-learning even with all kinds of limitations. This limitation is overcome by using social media as an alternative media in online learning in the midst of a crisis. Based on this background, this article focuses on how social media-based e-learning is used in areas where internet penetration is low during times of crisis. The use differences during and before the crisis occurred is important to examine as well as the methods used by the facilitators in implementing teaching and learning activities. Although there are many kinds of social media, this study focused on four social media that are predominantly used by instructors, which are WhatsApp, Instagram, YouTube, and Facebook. 


\section{$2 \quad$ Method}

This research is a descriptive study with a quantitative approach. It was conducted in August 2020. One of the universities in West Kalimantan was chosen as the research location. Fifteen informants who are lecturers were selected as respondents based on purposive sampling. The questionnaire was chosen as a quantitative data collection instrument. The questionnaire was distributed to respondents through the WhatsApp group. This questionnaire consisted of 18 items with indicators including e-learning knowledge and its policies, alternative use of e-learning, benefits and management, convenience, effectiveness, practicality, and hindrances. The data is then analyzed using percentages. The questionnaire was developed by the researchers. Before testing the research, the questionnaire validity was previously tested using Pearson's product momet and its reliability with Cronbach alpha. All items used in the questionnaire were valid $(\mathrm{P}, 0.05)$. Reliability has a value of $\mathrm{r} 11>0.40$. The obtained data were analyzed by using percentages. Quantitative data forms the basis for in-depth research through interviews. Interviews were conducted through a phone call to explore more of e-learning utilities and their various uses. Analysis using SWOC (Strength, Weakness, Opportunity, Challenge) was also carried out to understand the strengths, weaknesses, opportunities, and challenges of using social media as one of the last alternatives in online learning in the midst of a crisis, especially in areas with low internet penetration. Interactive Model Analysis was used to analyzed and is consisting of data collection, data reduction, data presentation, and concluding.

\section{$3 \quad$ Result and Discussion}

\subsection{Social media typology before and during crisis}

The online learning system is conducted without direct face-to-face meetings between teachers and students and is done online with an internet network connection using either a personal computer device; laptop; smartphones including tablets [25]. This learning activity requires an internet network with connectivity, accessibility, flexibility, and the ability to generate various learning interactions. There are many kinds of media and applications used in the online learning process in Kubu Raya regency. The use of Web.2.0 as a tool for teaching and learning is quite dominant similar to Google with its services (Mail, Meet, Classroom, Drive, Doc) and through an opensource Learning Management System such as Moodle, Udemy, or Schoology.

Of those tools, the most popular tools used for social media-based learning media in Pontianak are Facebook, Instagram, Youtube, and messaging services via WhatsApp. These three tools can be seen as social networks. This social network allows everyone to access information fast and easy. The fast and simple operation scheme makes this media accessible to people of all ages and backgrounds including lecturers and students at almost no expense. Studies in several countries also mentioned that the majority of higher education lecturers are more familiar with using social media sites and have frequently visited them in the past month than the Learning Management System services 
available [26], [27]. It is not surprising that $100 \%$ of the respondents are aware, downloaded, and utilizing social media with its multiple uses. These social media are WhatsApp, Youtube, Instagram, and Facebook respectively. As many as 53.3\% of respondents admitted using social media frequently for more than 4 hours a day. Meanwhile, $46.7 \%$ admitted to using it under 4 hours.

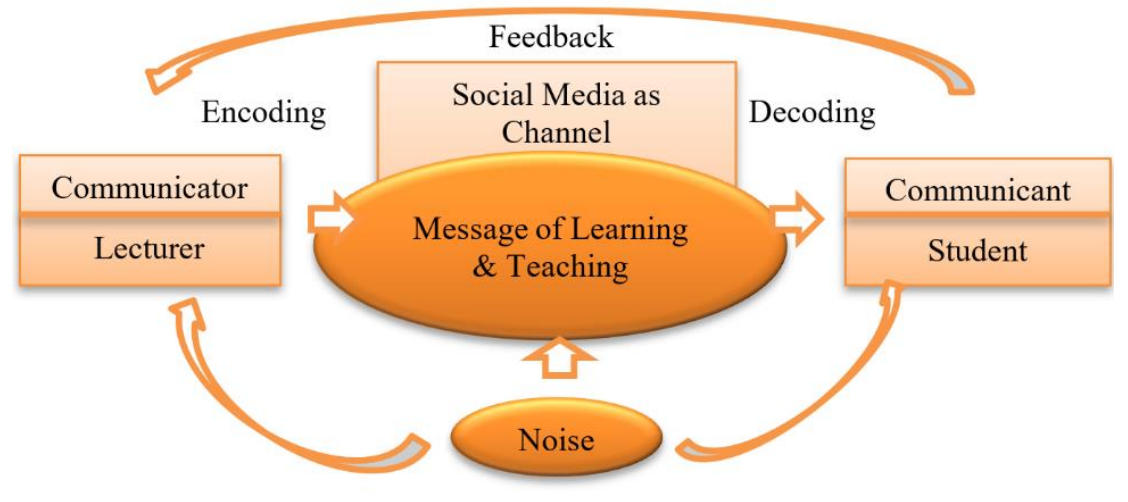

Fig. 1.Communication Process through social media

The Covid-19 pandemic and geographical factors, especially in West Kalimantan Province, have encouraged the distribution of social media usage. This distribution is due to social media popularity and its familiar usage to both lecturers and students. The birth of this technology was not developed for learning purposes, rather most use it for recreational purposes such as games, communication, and establishing online spaces for the expression of personal identity. However, this communication tool has a function similar to that in content management systems [28]. There has been a change in the function of social media as a tool for teaching and learning resources where $66.7 \%$ of respondents used it during the crisis, and the remaining $33.3 \%$ claimed to have used it before the crisis.

Social media has undergone a redefined function and is considered as a medium/channel in teaching and learning activities that connect communicators, which are lecturers and communicants, namely students. The communication process between the communicator and the communicant is the most important element in determining the success or failure of the message delivery process. Communicators with their use of social media must be able in facilitating and ensuring the course of learning to achieve effective learning outcomes. The communication effectiveness depends on the messages received, recognized, and followed through changes of the communicant [29]. Students as communicants are labelled as digital natives, their lives are surrounded by computers, smartphones, videogames, digital music players, and all the toys and gadgets in the digital era [30]. As web 2.0 social media technology developed in the market, 
students can easily adapt and adopted technology within the use of WhatsApp, Instagram, and Facebook. Meanwhile, lecturers that are labelled as digital immigrants need time to integrate technology into the learning process. If these tools can be integrated into the learning process, the messages will be conveyed effectively to students.

Table 1. The Differences in using Social Media before and during Pandemic

\begin{tabular}{|l|l|l|}
\hline \multicolumn{1}{|c|}{ Social Media } & \multicolumn{1}{|c|}{ Before Pandemic } & \multicolumn{1}{c|}{ During Pandemic } \\
\hline Purpose & Information and communication & Teaching and Learning \\
\hline Function & Personal interest & Medium/Channel, Learning resource \\
\hline Cost & Self-funding & Provided or subsidized by school/ government \\
\hline Time & Less than 4 hours & Intense, more than 4 hours \\
\hline Feature & Majority of personal (private) & Dominant for Public \\
\hline
\end{tabular}

The difference in the use of social media lies not only in the intended use and changes in function but also in financing issued. In general, the registration fee is very low and even free. This is one of the strong reasons that have resulted in many people downloaded and using the application. Before the pandemic, internet credit and its costs were borne individually, as it was private and hardly used as learning tools due to offlinebased learning. When a pandemic occurs, the government provides credit subsidies and data packages for teachers and lecturers with various policies. In more detail, each student is given 35 Gigabytes (GB) / month, while teachers and lecturers are given 42 GB / month starting from September to December. Higher education institutions also strengthen internet infrastructure by adding bandwidth and hotspot locations to make accessibility and affordability more factual.

Social media has its own interesting features. In WhatsApp (WA), for example, one of the most interesting features for lecturers is the instant and fast message services as well as a feature for creating groups. This group is different from social media (Instagram, Facebook, Twitter) which can be reached by many people. WA Groups are private and have boundaries. The group creator becomes the manager. The managers have the privilege to add, delete, communicate either one-way or two-way with participants without the need for consent from the WA group members. This feature is used by lecturers to create groups so that communication is more intense and private based on the subjects that are taught. All participants in the group have the same right to speak when two-way communication access is granted by the group administrator. Youtube is positioned as a learning material for course instructors. The information presented and its asynchronous nature allows students to repeat material anytime and anywhere. While on Instagram and Facebook, the most interesting thing is the change of use from what was originally for personal interest has shifted to learning resources media. These two social media often provide useful links for course purposes. Lecturers on several occasions also uploaded assignments and materials through these two media.

\subsection{Learning method and SWOC analysis}

Online learning practices must be carried out at various levels of education, from early childhood education to higher education. There should be no learning activities in 
the classroom as stipulated in various policies issued by the government regarding the Implementation of Education Policies in the Emergency for the Spread of Corona virus (COVID-19). This is the right step even without adequate preparation from education stakeholders. As a result, many lecturers were shocked by this drastic and revolutionary change. Lecturers are required to be able to implement online learning media with relatively less preparation time following the demands of achieving learning outcomes. Lecturers must design creative learning by shifting all class activities that are usually carried out face-to-face or blended learning to online classes as a whole.

Online learning exists as a panacea in the learning process. Panacea is bitter, but it has to be done. For lecturers, it takes time to adapt and adopt the available learning management system. They are looking for shortcuts, simple solutions to optimize the use of social media as an alternative to online learning. Social media is used as a smart tactic in managing and holding as many classes as possible virtually with various models. Social media was chosen as $86.7 \%$ of respondents considered it as an easy-to-use application with its utility. The practicality is reflected as the majority of students own it. One media frequency between lecturers and students will simplify communication so that effective communication will be created. On the other hand, $13.3 \%$ of respondents said they are still learning how to use social media. Respondents who expressed difficulties are the digital immigrants (born before 1980) who need time to adapt. Adaptation is a non-negotiable imperative. On the other hand, digital natives (born after 1980) enjoy online learning and combine it with the university learning management system. Interestingly, even though it was considered difficult, as many as $93.3 \%$ of respondents rated social media as the most practical application. Through this social media, teachers can ensure that their students follow the learning simultaneously (synchronously) even though they are in different places.

Online learning using social media though it comes with many advantages it is not without weaknesses and challenges. Its most prominent strengths are its effectiveness, flexibility, and popularity. Meetings between lecturers and students are not limited to space and time from Monday to Friday like conventional lectures. The world becomes a classroom which means that optimizing its use allows students and lecturers to interact with flexible learning time. Although this does not mean lectures are held on nights or weekends. This adjustability is supported by the fact that social media has become part of students and some lecturers' daily life. Effective communication is easier to achieve when both parties understand each other. 




Fig. 2.TSWOC Table the Use of Social Media in Time of Crisis

The accessibility issues, such as internet connection and cost, are major challenges in online learning [31], [32]. Accessibility is still a challenge as the geographic location differences of the coastal area and hills side affected internet connectivity. However, during the crisis, the cost of internet credit and data is not a problem following government and institutions full subsidies. The research findings revealed that students and lecturers are not ready for new learning experiences. Their unpreparedness is due to a crisis that had never occurred in the past. The conventional learning mindset through face-to-face learning is still intact and has been internalized for a long time that they seem reluctant to have the courage to start the online-based learning processes.

\section{Conclusion}

Online learning is the last alternative for teaching and learning activities are recommenced. Social media is the answer amid the limited internet infrastructure in the regions and lecturers' ability to adapt with time to applied learning management system prepared by the institutions. The fact that there is a change in the function of social media is strong evidence that lecturers are moving and continuing to adapt. Students who make technology a part of Lebenswelt are ready and enthusiastic. On the contrary, students can use this social media fast and practically. Lecturers' ability to update and student's quick usage of social media has an impact on effective learning. Simple learning methods that can be conducted, such as questions and answers, giving assignments, delivering material both synchronously and asynchronously. Support from the government and institutions increases the user's online learning ability. Accessibility in areas with different geographic typologies as well lecturers and students' mindset is a challenge that must be faced. If social media is familiar and accepted in times of crisis, further research is needed to see the effectiveness of its use in teaching and learning activities. 


\section{$5 \quad$ References}

[1] P. Carlsson-Szlezak, M. Reeves, and P. Swartz, "What coronavirus could mean for the global economy," Harvard Business Review, vol. 3, 2020.

[2] P. K. Ozili and T. Arun, "Spillover of COVID-19: impact on the Global Economy," Available at SSRN 3562570, 2020.

[3] R. H. Huang, D. J. Liu, A. Tlili, J. F. Yang, and H. H. Wang, "Handbook on facilitating flexible learning during educational disruption: The Chinese experience in maintaining undisrupted learning in COVID-19 Outbreak," Beijing: Smart Learning Institute of Beijing Normal University, 2020.

[4] S. Dhawan, "Online learning: A panacea in the time of COVID-19 crisis," Journal of Educational Technology Systems, vol. 49, no. 1, pp. 5-22, 2020. https://doi.org/10.1177/ 0047239520934018

[5] F. E. B. Setyawan and R. Lestari, "Challenges of Stay-At-Home Policy Implementation During the Coronavirus (Covid-19) Pandemic in Indonesia," Jurnal Administrasi Kesehatan Indonesia, vol. 8, no. 2, pp. 15-20, 2020. https://doi.org/10.20473/jaki.v8i2.2020.15-20

[6] D. Zhang, J. L. Zhao, L. Zhou, and J. F. Nunamaker Jr, "Can e-learning replace classroom learning?" Communications of the ACM, vol. 47, no. 5, pp. 75-79, 2004. https://doi.org/10.1145/986213.986216

[7] J. L. Moore, C. Dickson-Deane, and K. Galyen, "e-Learning, online learning, and distance learning environments: Are they the same?" The Internet and Higher Education, vol. 14, no. 2, pp. 129-135, 2011. https://doi.org/10.1016/j.iheduc.2010.10.001

[8] K. Ayebi-Arthur, "E-learning, resilience and change in higher education: Helping a university cope after a natural disaster," E-Learning and Digital Media, vol. 14, no. 5, pp. 259274, 2017. https://doi.org/10.1177/2042753017751712

[9] M. Kebritchi, A. Lipschuetz, and L. Santiague, "Issues and challenges for teaching successful online courses in higher education: A literature review," Journal of Educational Technology Systems, vol. 46, no. 1, pp. 4-29, 2017. https://doi.org/10.1177/0047239516661713

[10] A. Assareh and M. H. Bidokht, "Barriers to e-teaching and e-learning," Procedia Computer Science, vol. 3, pp. 791-795, 2011. https://doi.org/10.1016/j.procs.2010.12.129

[11] C. Juliane, A. A. Arman, H. S. Sastramihardja, and I. Supriana, "Digital Teaching Learning for Digital Native; Tantangan dan Peluang," Jurnal Ilmiah Rekayasa dan Manajemen Sistem Informasi, vol. 3, no. 2, pp. 29-35, 2017. https://doi.org/10.24014/rmsi.v6i1

[12] L. Perguna, I. Idris, and I. Irawan, "From Content to Context: Understanding Introduction to Sociology through MOOC," International Journal of Emerging Technologies in Learning (iJET), vol. 15, no. 7, pp. 188-195, 2020. https://doi.org/10.3991/ijet.v15i07.13467

[13] M. A. S. Enriquez, "Students' Perceptions on the Effectiveness of the Use of Edmodo as a Supplementary Tool for Learning," in DLSU Research Congress, 2014, pp. 1-6.

[14] A. S. Sicat, "Enhancing college students' proficiency in business writing via schoology," International Journal of Education and Research, vol. 3, no. 1, pp. 159-178, 2015.

[15] S. Iftakhar, "Google classroom: what works and how," Journal of Education and Social Sciences, vol. 3, no. 1, pp. 12-18, 2016.

[16] V. Kumar and P. Nanda, "Social Media as a Tool in Higher Education: A Pedagogical Perspective," in Handbook of Research on Diverse Teaching Strategies for the TechnologyRich Classroom, IGI Global, 2020, pp. 239-253. https://doi.org/10.4018/978-1-7998-02389.ch016

[17] S. So, "Mobile instant messaging support for teaching and learning in higher education," The Internet and Higher Education, vol. 31, pp. 32-42, 2016. https://doi.org/10.1016/ j.iheduc.2016.06.001

[18] L. A. Perguna, I. Idris, and Widianto,Ahmad Arif, "From Paper to Screen: Encouraging Theory of Sociology through Sociopedia by Heutagogy Approcah - " International Journal 
of Interactive Mobile Technologies (iJIM), vol. 15, no. 1, pp. 155-167, 2021. https://doi.org/10.3991/ijim.v15i01.14357

[19] Z. Zaharah, G. I. Kirilova, and A. Windarti, "Impact of Corona Virus Outbreak Towards Teaching and Learning Activities in Indonesia," SALAM: Jurnal Sosial dan Budaya Syar-i, vol. 7, no. 3, pp. 269-282, 2020. https://doi.org/10.15408/sjsbs.v7i3.15104

[20] D. W. Surry, D. C. Ensminger, and M. Haab, "A model for integrating instructional technology into higher education," British journal of educational technology, vol. 36, no. 2, pp. 327-329, 2005. https://doi.org/10.1111/j.1467-8535.2005.00461.x

[21] D. Kisanga and G. Ireson, "Barriers and strategies on adoption of e-learning in Tanzanian higher learning institutions: Lessons for adopters," International Journal of Education and Development using ICT, vol. 11, no. 2, 2015.

[22] F. Elloumi, "Value chain analysis: A strategic approach to online learning," Theory and practice of online learning, vol. 61, 2004.

[23] R. G. Saadé, "Web-based educational information system for enhanced learning, EISEL: Student assessment," Journal of Information Technology Education: Research, vol. 2, no. 1, pp. 267-277, 2003. https://doi.org/10.28945/327

[24] D. R. Garrison, T. Anderson, and W. Archer, "A theory of critical inquiry in online distance education," Handbook of distance education, vol. 1, pp. 113-127, 2003.

[25] J. Gikas and M. M. Grant, "Mobile computing devices in higher education: Student perspectives on learning with cellphones, smartphones \& social media," The Internet and Higher Education, vol. 19, pp. 18-26, 2013. https://doi.org/10.1016/j.iheduc.2013.06.002

[26] M. Moran, J. Seaman, and H. Tinti-Kane, "Teaching, Learning, and Sharing: How Today's Higher Education Faculty Use Social Media.,” Babson Survey Research Group, 2011.

[27] W. D. Chawinga, "Taking social media to a university classroom: teaching and learning using Twitter and blogs," International Journal of Educational Technology in Higher Education, vol. 14, no. 1, p. 3, 2017. https://doi.org/10.1186/s41239-017-0041-6

[28] C. Crook, "Web 2.0 technologies for learning: The current landscape-opportunities, challenges and tensions," 2008.

[29] D. Mulyana, Metode Penelitian Kulaitatif: Paradigma Baru Ilmu Komunikasi dan Ilmu Sosial Ilmu Lainnya, Cet. VI, 2008.

[30] M. Prensky, "H. sapiens digital: From digital immigrants and digital natives to digital wisdom," Innovate: journal of online education, vol. 5, no. 3, 2009. https://doi.org/10. 4135/9781483387765.n6

[31] Z. Berge and L. Muilenberg, Survey of student barriers to e-learning. Retrieved April, 2005.

[32] A. Ahmed and W. E. Nwagwu, "Challenges and opportunities of e-learning networks in Africa," Development, vol. 49, no. 2, pp. 86-92, 2006. https://doi.org/10.1057/palgrave.development. 1100250

\section{Authors}

Luhung Achmad Perguna is from Universitas Negeri Malang, Indonesia. luhung.fis@um.ac.id

Netty Apriyanti is from Universiti of Malaya, Kuala Lumpur, Malaysia

Dedeh Kurniasih is from Universitas Muhammadiyah Pontianak, Indonesia

Article submitted 2021-01-13. Resubmitted 2021-02-24. Final acceptance 2021-02-25. Final version published as submitted by the authors. 